\title{
Review on Factors Affecting the Participation of Smallholder Farmers in Improved Chicken Rearing in Ethiopia
}

\author{
Tariku Bachano \\ Jimma University College of Agriculture and Veterinary Medicine, \\ Department Rural Development and Agricultural Extension
}

\begin{abstract}
The main aim of this seminar paper is to review factors affecting the participation of smallholder farmers in improved chicken rearing in Ethiopia. Improved chicken rearing plays an important role by increasing smallholder farmers' household food security and income generation as well as increasing gender equity, amongst the rural poor. To increase the chicken contribution to income and dietary diversity of the household; a ministry of agriculture and rural development of the country have been multiplied and disseminated several improved chicken breeds to the smallholder farmers over the last fifty years in different parts of regions of Ethiopia. Improved chickens such as Rhode Island Red, White Leghorn, Bovine brown, and Issa brown, were imported and disseminated to smallholder farmers to increase egg and meat production, income generation, job creation for the smallholder farmers, and genetically to improve the native chicken breeds through on-farm research and public extension programs in Ethiopia. Even if an improved chicken were disseminated to smallholder farmers in the country, smallholder farmers' discussion to participate in improved chicken rearing system was limited to traditional rearing system and different factors as well as different challenges. Those challenges and factors are lack of extension follow-up, lack of complementary inputs, diseases, unavailability of credit services, market problem, agro-ecological problem, and less gender participation. Based on this seminar paper of review, it was concluded that extension agencies and other concerned departments should manipulate these crucial factors to bring about inclusive and desirable changes in the participation of smallholder farmers in improved chicken rearing that; can towards improved poultry technologies in Ethiopia.
\end{abstract}

Keywords: Ethiopia, Improved chicken rearing, Participation, Smallholder farmers

DOI: $10.7176 / \mathrm{JBAH} / 11-2-02$

Publication date: January $31^{\text {st }} 2021$

\section{INTRODUCTION}

\subsection{Background}

Rural smallholders throughout the world rear all species of poultry (Tesfahun et al., 2018). In most developing countries rural poultry plays a significant role in improving the nutritional status, income, food security, and livelihood of many smallholders (Zewdu et al., 2013). Ethiopia ranks first in Africa and the tenth in the world in livestock production, which plays important socioeconomic roles for the rural poor (Fessiha et al., 2010; Sisay et al., 2017).

The poultry population in Ethiopia is estimated to be 56.87 million (CSA, 2015). Of these, in breed type, $95.86 \%, 2.79 \%$, and $1.35 \%$ of the total poultry are indigenous, hybrid, and improved, respectively (CSA, 2017). Rearing of the chicken plays important role in both the rural and urban economies of Ethiopia (Kejela et al., 2019). Currently, Ethiopian MoARD is mandated to poultry extension development package through the distribution of improvedlexotic chicken breeds for smallholder farmers (Ermias et al., 2015). To increase the chicken contribution to income and dietary diversity of the household; a ministry of agriculture and rural development of the country have been multiplied and disseminated several exotic chicken breeds to the farmers over the last 50 years in different parts of the country (Demeke, 2008; Molla et al., 2010; Hinsemu, 2018). Exotic/improved chicken breeds were promoted and disseminated in the rural and peri-urban parts of Ethiopia, to improve the productivity of the poultry to increase the income of farmers (Abadi, et al., 2017).

Improved breeds such as Rhode Island Red (RIR), White Leghorn (WL), Bovans Brown (BB), and Issa Brown (IB), were imported to rural smallholder poultry producers through public extension programs to improve egg and meat production in Ethiopia (Bogale and Edae, 2020). Even if different improved chicken have been distributed throughout in the rural parts of the country, smallholder farmers' participation were low. Limited empirical evidence available on the adoption of exotic chickens in Ethiopia shows that after 40 years of dissemination exotic chicken breeds contribute less than $2 \%$ to the national eggs and meat production (Wondmeneh, et al., 2014). The Rhode Island Red chicken breed was not adopted by farmers due to lack of awareness in most rural parts of Ethiopia.

Ethiopian poultry rearing systems comprise both traditional and modern production systems. Ninety-nine percent of the poultry population consists of local breed types under traditional management (Asgedom, 2007; Dana et al., 2010). The latest figures available indicate that village poultry contributes $98.5 \%$ and $99.2 \%$ of the national egg and poultry meat production (Asresie et al., 2015). Birds are owned by individual households and are 
maintained under a scavenging system, with few or no inputs for housing, feeding, and health care (Asgedom, 2007; Hailemichael et al., 2016)._Smallholder farmers' discussion to participate in improved chicken rearing in Ethiopia was limited by factors as well as challenges; such as lack of extension follow-up, lack of complementary inputs, diseases, unavailability of credit services, and market problems (Teklewold et al., 2006; Alemneh \& Getabalew, 2019). According to Kibreab et al. (2016), to increase the productivity of the poultry sector, there are factors such as market problem, chicken management practices on feed and feeding is poor.

Therefore, the intent of seminar is to review the different secondary published and unpublished journals, articles, review papers, and manuscripts' which related to improved chicken rearing technologies in Ethiopia.

\subsection{Objectives}

\subsubsection{General objective}

The overall objective of this seminar is to review factors affecting the participation of smallholder farmers in improved chicken rearing in Ethiopia.

\subsubsection{Specific objectives}

E To explore the current status of improved chicken rearing in Ethiopia.

- To review factors affecting smallholder farmers' discussion to participate in improved chicken rearing in Ethiopia.

- To explore challenges and opportunities of improved chicken rearing in Ethiopia.

\subsection{Significances}

The main significance of this review paper is to provide a summary of the literature concerning improved chicken rearing technologies. There are not many reviews related to the title of the smallholder farmers' participation in improved chicken rearing, as a result, it can be an opportunity for the next scholars, researchers, and program planners who study related to this title to use as a reference.

\section{Methodology}

The information presented here has been collected using different methodologies. A desk reviews such as extension department of the Ministry of Agriculture (MoA), National Poultry Research Commodity Strategy (NPRCS), Ethiopia Livestock Master Plan (ELMP) a contribution to the growth and transformation Plan II (2015 -2030), the International Livestock Research Institute (ILRI) and Ethiopian Agricultural Sector Policy (EAP). And also related published and unpublished reviews, and articles; were collected from different authors. To make the review articles briefer, in addition to narrations, and figures were also used as reviewing techniques.

\section{LITERATURE REVIEW}

\subsection{Basic Concepts and Definitions}

Smallholder farmer: defined as those with a low asset base, limited resource endowments, poor resources, low farming technology, fragile market relationships, low access to services, finance, and information relative to commercial farmers (Dixon et al., 2003; World Bank, 2003; Becx et al., 2011).

Poultry: all domestic birds kept for human food (meat and eggs) production including chickens, ducks, ostrich, guinea fowl, doves, and pigeons (Getu, 2014). From poultry species, chicken is the most popular and worldwide in terms of their economic importance (Nigussie, 2011).

\subsection{Current Status of Improved Chicken Rearing in Ethiopia \\ 3.2.1 Ethiopian improved chicken population and distribution}

Even if there is no evidence indicating the exact time and locations of the introduction of the first batch of improved breeds of chickens into Ethiopia, it was believed that the improved breeds of chickens were introduced by the missionaries sometime in the mid decades of the last century (Molla, 2010). Four breeds of exotic chicken (Rhode Island Red, Australop, New Hampshire, and White Leghorns) were imported to Jimma and Haromaya in 1953 and 1956, respectively under the USAID project (Demeke, 2007). Milkias (2016) reviewed that; due to the low performance of indigenous chicken, the introductions of highly productive breeds of improved chicken were practiced in urban, peri-urban, and rural areas in the country.

The MoARD of Ethiopia has established 14 poultry breeding and/or rearing centers (Demeke, 2008). Tegegne et al. (2010) reported 14 poultry breeding and multiplication centers. These centers are located in different regions; Mekelle and Adigrat in Tigray Region, Andassa and Combolcha in Amhara Region, Adama, Adelle, Bedelle and Nekemt in Oromiya Region, Hawassa, Bonga, Gubre and Wolayita in South Nation Nationalist and People Region and, Dire Dawa and Harar (Tegegne et al., 2010) and they have a capacity of delivering nearly 1,236,150 day-old chicks (DOs) and 485,800 pullets and cockerels (Alemu et al., 2008).

The major objective of the centers was a distribution of exotic chicken breeds' (Rhode Island Red, Bovan Brown and White Leghorn) fertile eggs, baby chicks, pullets, and cockerels to smallholder farmers to increase egg 
and meat production, and genetically improve the native chicken breeds (Alemu et al., 2008; Demeke, 2008; Tegegne et al., 2010).

The centers also provide in-service training to farmers and extension workers and provide about $50 \%$ price subsidy by giving the priority to women (Alemu et al., 2008). However, since a few years back, centers suffered a shortage of financial resources, lack of replacement breeding stocks, and periodic disease.

Currently, the centers give up a provision of price subsidies to support farmers. Previously, the extension development system had promoted schemes in which cockerels from selected strains were reared up to 15 to 20 weeks of age and then exchanged for local cockerels owned by rural farmers (Ermias, 2015). However, the supply of exotic pullets and cockerels from the government poultry multiplication centers has not been adequate with the demand of the technology participants (Demeke, 2008). A few years back, the regional agricultural bureau included a poultry technology package in their new extension development programs. The scheme involves distributing five pullets and a cockerel to individual farmers (Teklewold et al., 2006).

Table 1: Chicken distribution in Ethiopia

\begin{tabular}{|c|c|c|c|}
\hline \multirow{2}{*}{ Year } & \multicolumn{3}{|c|}{ Breeds in percent } \\
\cline { 2 - 4 } & Indigenous $\backslash$ Local & Hybrid & Exotic/Improved \\
\hline 2010 & 97.3 & 0.38 & 2.32 \\
\hline 2012 & 97 & 0.58 & 2.42 \\
\hline 2013 & 96.83 & 0.8 & 2.37 \\
\hline 2014 & 96.9 & 0.54 & 2.5 \\
\hline 2017 & 94.33. & 3.21 & 2.49 \\
\hline
\end{tabular}

\section{Source: CSA (2017)}

The extension department of the Ministry of Agriculture (MoA) of Ethiopia has shown more preference and interest in the use of the Rhode Island Red (RIR) breed of chicken, dual-purpose that could serve both as a source of egg and meat production. In recent years, the Egyptian Fayoumi breed has been imported with the expectation of better productivity, adaptation, and disease resistance than the other exotic breeds in a rural setting of Ethiopia (Wilson, 2010).

\subsubsection{Production performance of improved chicken}

It was indicated that all the imported breeds of chickens performed well under the intensive management system in Ethiopia. Currently, the commercial breeds are either layers or broilers. There are also pure, exotic breeds but currently they are not available in the commercial markets of Ethiopia (Alemneh and Getabalew, 2019). Formerly Rhode Island Red and White Leghorns were available in Ethiopia. We can roughly divide commercial breeds according to their main production aim as egg-laying, mainly with lightweight laying breeds or layers; meat production, mainly by heavyweight breeds or broilers; both egg-laying and meat production by so-called dualpurpose breeds (Van Eekeren, 2016).

Table 2: Chicken production performance in Ethiopia

\begin{tabular}{|c|c|c|c|}
\hline \multirow[t]{2}{*}{ Production performance } & \multicolumn{3}{|c|}{ Breeds } \\
\hline & Indigenous & Hybrid & Exotic/Improved \\
\hline Egg production/year/hen & $30-60$ & $156-200$ & 250 \\
\hline Egg weight in gram & 38 & $49-56$ & 60 \\
\hline The egg-laying period in days & 21 & 36 & 105 \\
\hline Bodyweight at 6 months & 1.5 & $1.6-1.65$ & 1.76 \\
\hline
\end{tabular}

Source: Alemneh and Getachew (2019)

\subsubsection{Types of preferred improved chicken in Ethiopia}

\subsubsection{Bovans brown}

According to Hinsemu (2018), review, this breed was formerly known as Bovans Goldline and is a hybrid of Rhode Island Red (cock) and Light Sussex (a hen). Bovans Brown (BB) is a brown feathered, brown egg layer that can meet the expectations of a variety of egg producers with different objectives (Figure 1). It is the bird of choice for today's egg farmers who expect high egg numbers and a forgiving bird essential ingredient to keeping business profitable. It not only performs well for the egg producer with traditional production facilities but is very docile making it's the perfect bird for alternative production methods as well. 


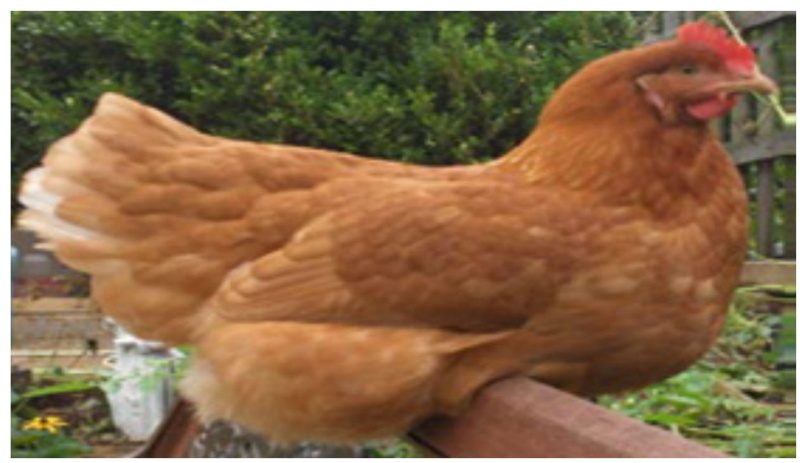

Figure 1: Bovans Brown

Source: Hinsemu (2018)

Ermias et al. (2015) researched the characterization of husbandry practices, adoption, and impact of village poultry technology packages in the central Oromiya Region, Ethiopia. In their study, they found BB chicken breed adoption was higher than other chicken breeds by smallholder farmers.

A survey conducted by Getiso et al.,(2017), to identify traits of preference mainly on egg production, body size and meat production, scavenging ability, disease resistance, and physical appearance of Bovans brown (BB) chickens breed under village production system in three agro-ecologies of Southern Nations, Nationalities, and the Peoples Regional State of Ethiopia they concluded under their research that, 94.4\% of respondents on average in all agro-ecologies select bovans brown for egg production.

\subsubsection{Issa brown}

Like Bovans Brown, Issa Brown is also available in Ethiopia. This layer is a hybrid of Rhode Island Red (a hen) and Rhode Island White cock. It is known for its high egg production of approximately 300 eggs per hen in the first year of lying. They are easy to rise and prolific producers of large richly coloured brown eggs of excellent shell quality. They are quiet and friendly and easily trained to lay in their nest (Hinsemu, 2018).

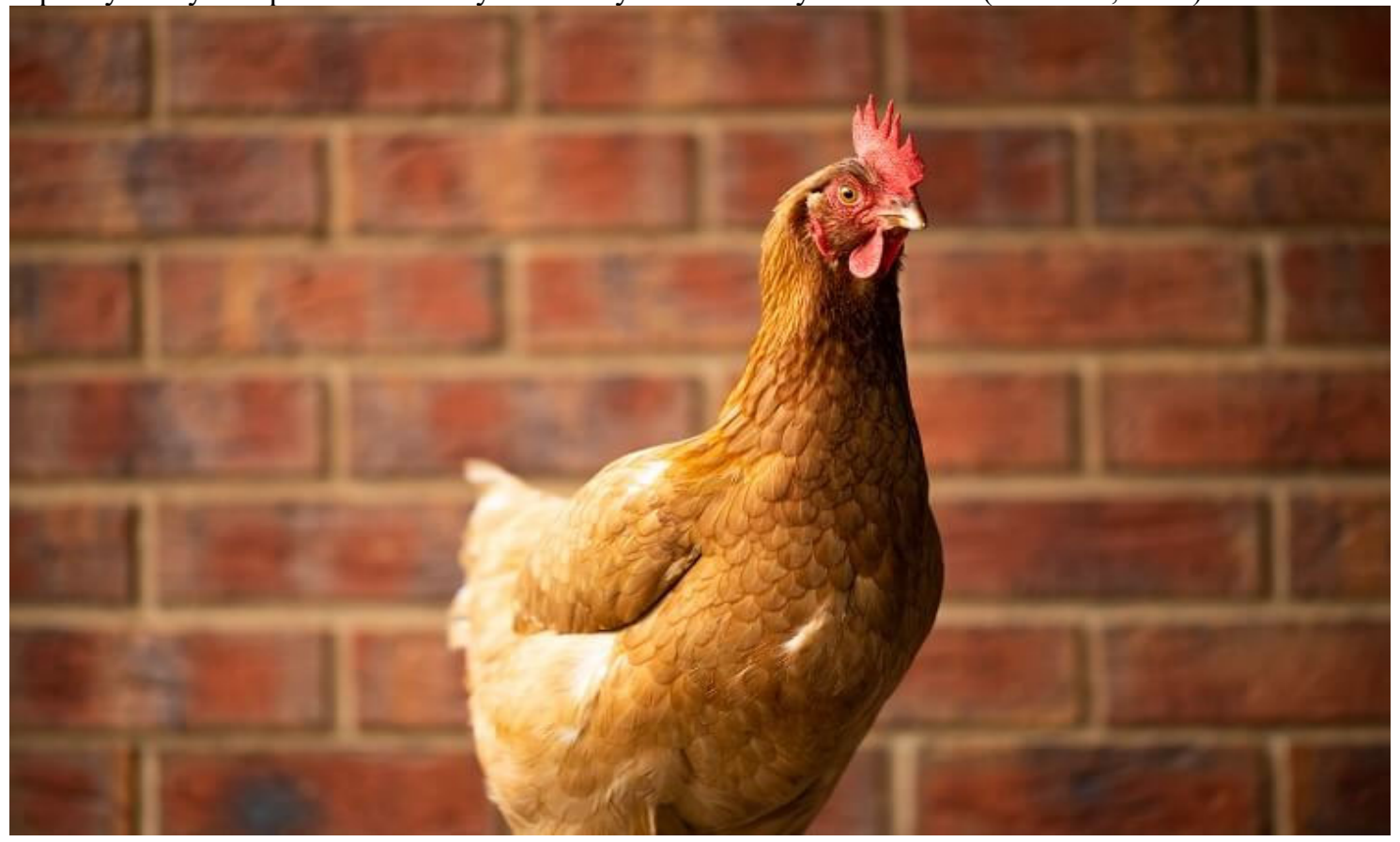

Figure 2: Issa Brown

Source: Chris (2020)

\subsubsection{White leghorn}

White Leghorns are known for laying lots of white eggs. They need less feed, due to their small size. White Leghorns are therefore Very efficient layers. At the end of the laying period, they give relatively little meat (Haftu, 2016).

\subsubsection{Fayoumi}

Additionally, there is a chicken breed that is imported to Ethiopia from Egypt for trial purposes namely the Fayoumi breed. They are known for their best adaptability in the harsh, hot, and arid environment of Egypt and they have been in trial in the lowlands of Ethiopia by the Ethiopian agriculture research institute (EARI). They are breeds of dual-purpose and can be used both for egg production and meat. Since it is a short time they are 
introduced and still going on, there is no clear information about their performance in Ethiopia and they are only distributed on trial bases (Hinsemu, 2018).

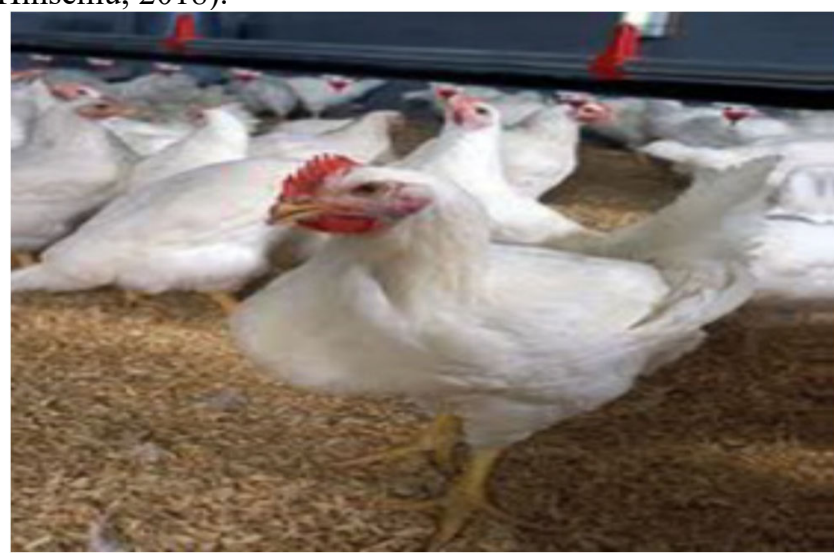

Figure 3: Fayoumi

Source: Hinsemu (2018)

Biratu \& Haile (2016) researched at Jimma zone to demonstrate and evaluate a full package of improved dual-purpose Koekoek chicken under farmers' management conditions. In their study; they concluded that; smallholder farmers' acceptable performance indicating the possibility of using improved breeds of chicken with a little additional input on housing, feeding, and health management. Fayoumi chicken breed was the most $(\mathrm{P}<0.001)$ preferred breed by farmers in the lowland agro-ecology Ermias et al. (2015).

\subsection{Chicken Rearing Systems}

Chicken can be reared in different management and production systems. Based on chicken breed type, input and output level, mortality rate, type of producer, the purpose of production, length of broodiness, growth rate, and several chickens reared (Yenesew et al., 2015; Alemneh, and Getabalew, 2019).

\subsubsection{Free-range chicken rearing system}

It is practiced by rural farmers of the country and its objectives are for household consumption and as a source of additional income for the household. It covers $95-98 \%$ of the chicken production system of the country and it is not profitable since it is not market-oriented. It contains small flock sizes (5-20 chickens per household) which are indigenous breed types mostly depend on locally available feed material as a supplement with low health services (Yenesew et al., 2015). The system characterized by the production of a small number of low-yielding chickens (40-60 eggs/hen per year), an average flock size of 7-10 mature birds per household, and with little or no additional inputs for feeding and health care, except the provision of shelter during the night time. Hatching and brooding are entirely natural, by broody hens, but there is often very high chick mortality, of 25-88\% (Tadelle et al., 2003). Women are the primary owners and managers of chickens in the traditional poultry production sector (Nasser et al., 2000).

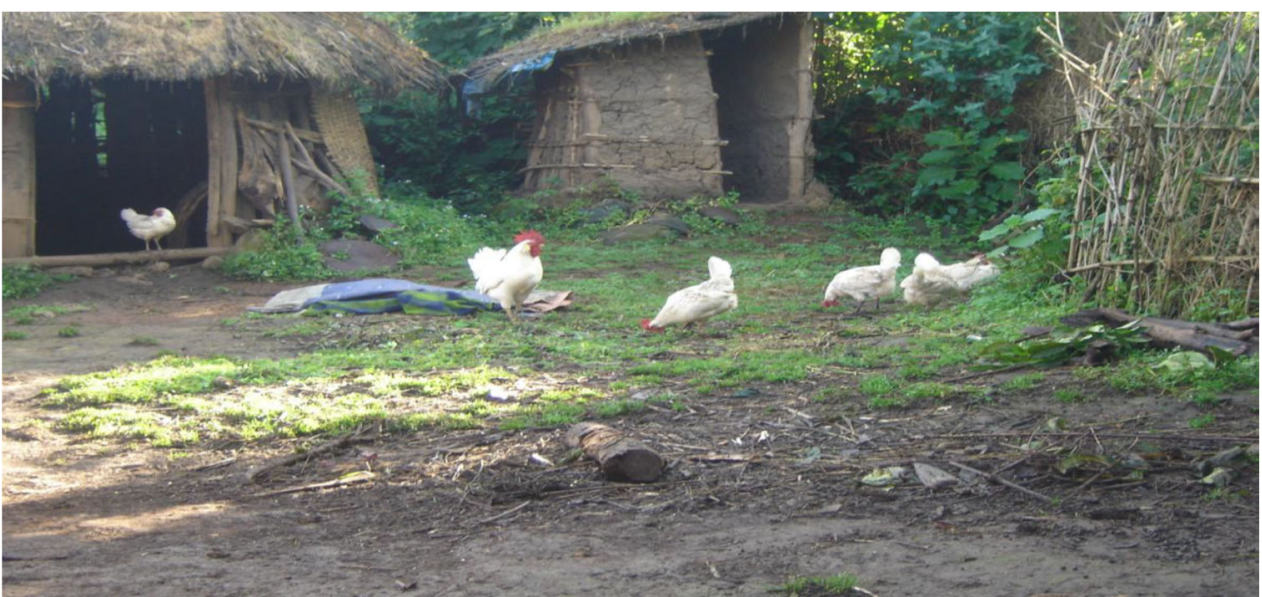

Source: Yenesew et al. (2015)

\subsubsection{Semi-intensive chicken rearing system}

Figure 4: Free-range chicken rearing system

Mostly these systems concentrate on exotic (nonindigenous), dual-purpose chicken breeds, with the potential to lay about 150-200 eggs/bird per year. Depending on the available scavenging feed resources in the area, the flock size under this system ranges from 10-50 chickens (Habte et al., 2017). Sisay et al., (2017) studied research on 
population dynamics and performance of exotic versus indigenous chicken population in the selected districts of North Western Amhara, Ethiopia. Under their result, they concluded that; about $91.12 \%$ of respondents used the backyard chicken management system in the studied area, whereas, $8.89 \%$ of smallholder farmers kept their chicken by the semi-intensive management system.

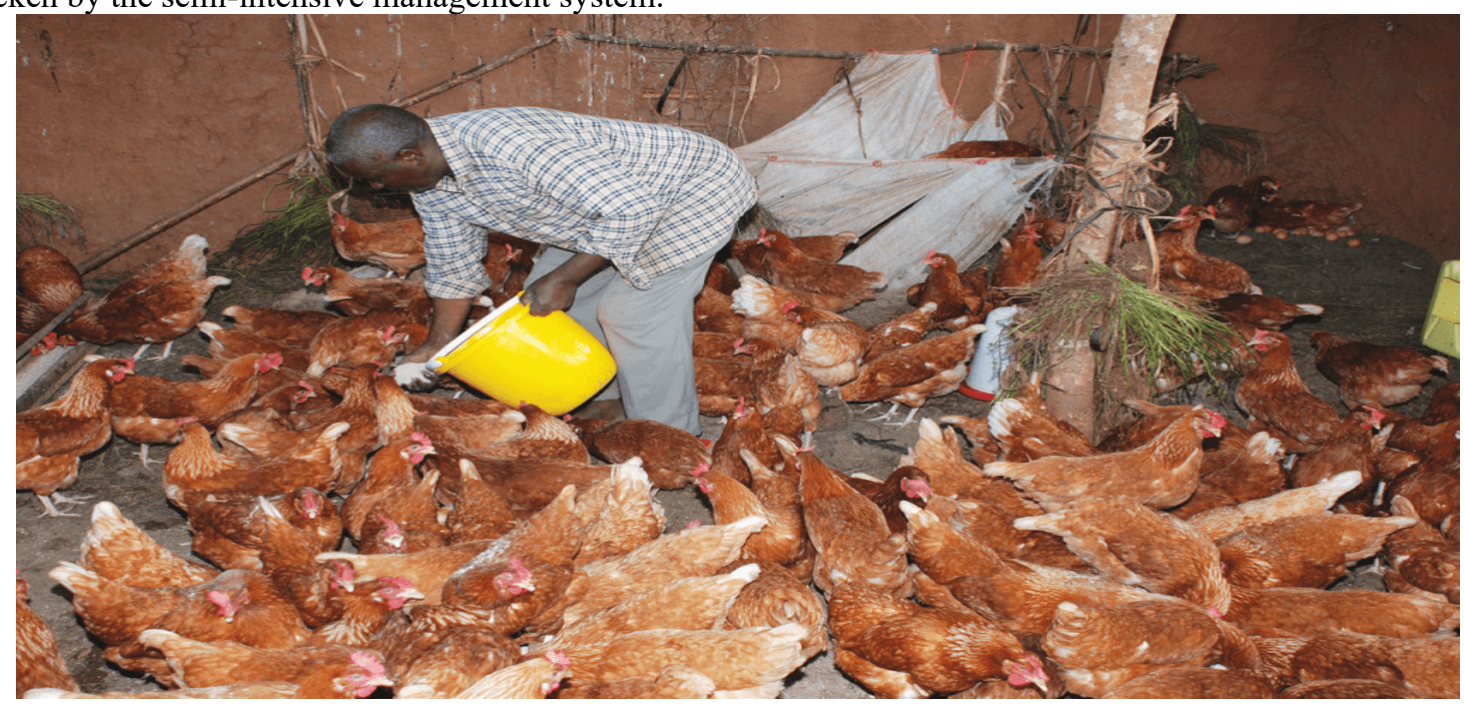

Figure 5: Semi-intensive chicken rearing system

Source: Afrimash (2020)

\subsubsection{Intensive chicken rearing system}

Depending on the level of production and scale of commercialization, there are two types of intensive chicken production.

\subsubsection{Small-scale commercial poultry rearing system}

The small scale intensive poultry is a newly emerging system in urban and peri-urban areas, where either broilers or egg type exotic breeds of chicken are produced along commercial lines using relatively modern management methods. This activity is being undertaken as a source of income in and around major cities and towns (Molla, 2010).

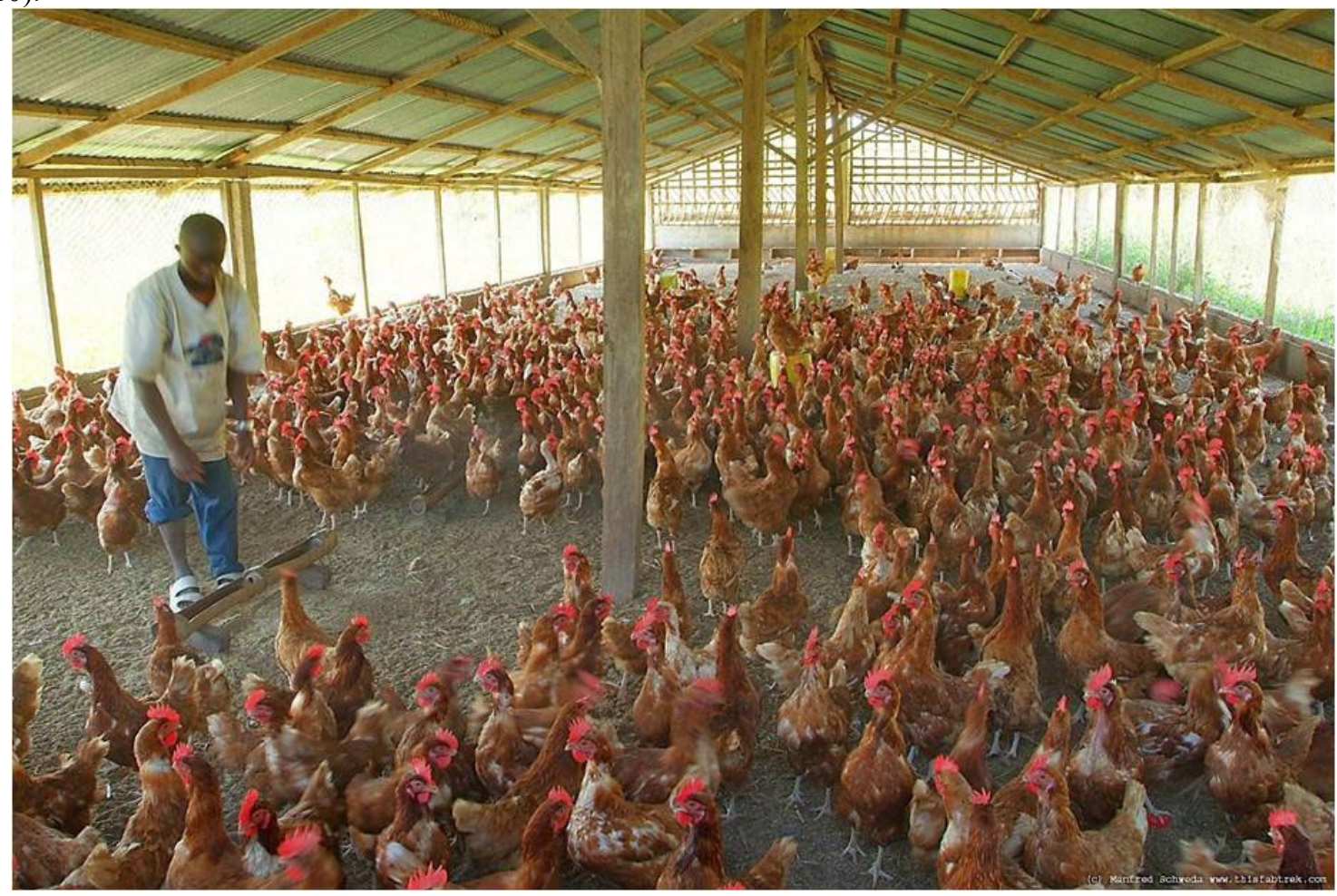

Source: Temi (2020)

Figure 6: Small-scale commercial poultry rearing system 


\subsubsection{Large-scale commercial rearing system}

This system heavily depends on imported exotic breeds that require intensive inputs such as feed, housing, health, and modern management systems. It is estimated that this sector accounts for nearly $2 \%$ of the Ethiopian poultry population. This system is characterized by a higher level of productivity and entirely market-oriented to meet the large poultry demand in major cities. The existence of somehow better bio-security practices has reduced chicken mortality rates to merely $5 \%$ (Bush, 2006).

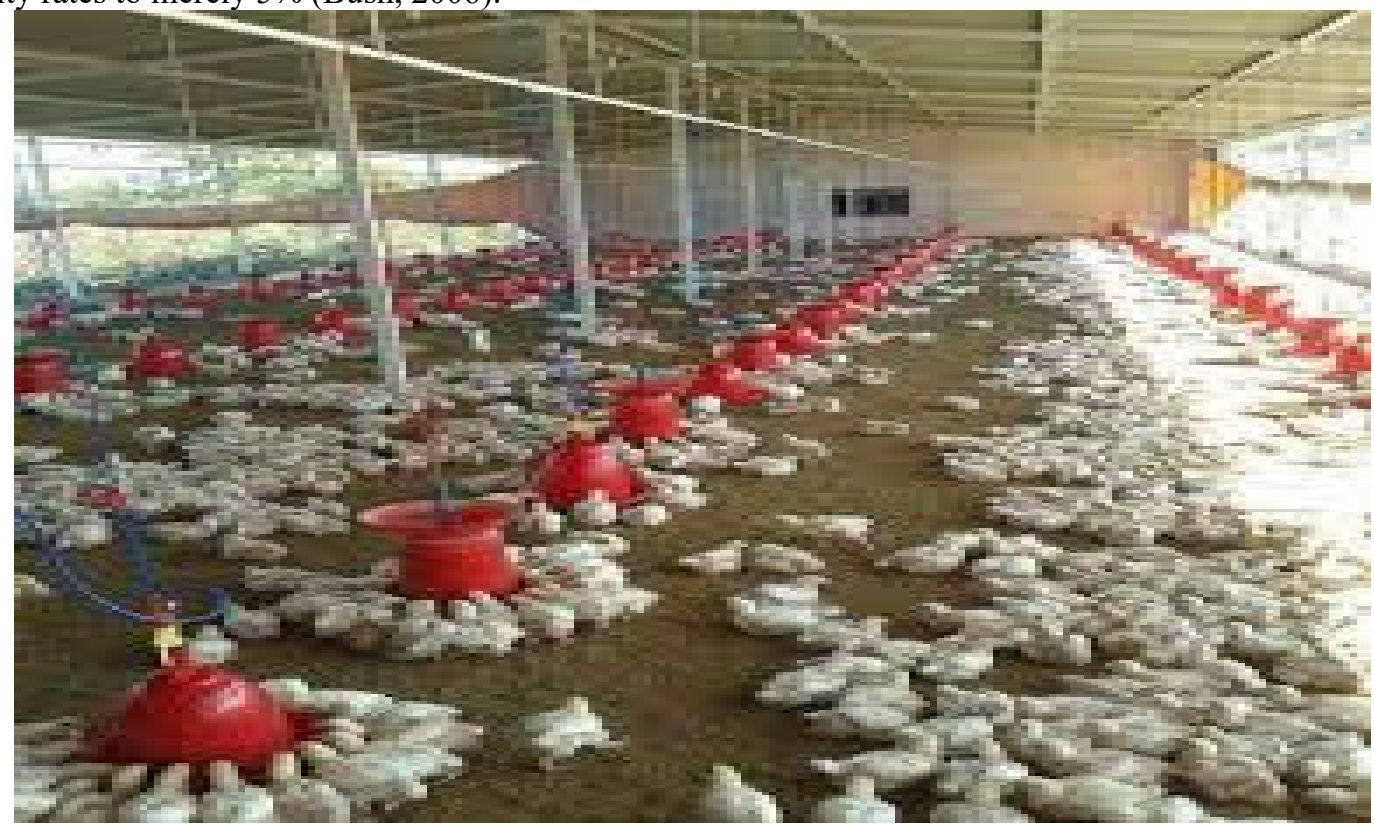

Figure 7: Large-scale commercial rearing system

Source: Temi (2020)

The large scale commercial poultry Provide fertile eggs, table eggs, day-old chicks, broiler meat, and adult breeding stocks to the small scale modern poultry farms. The general indications are that the intensive poultry industry plays a key role in supplying poultry meat and eggs to urban markets at a competitive price. The industry also employs a range of workers from poultry attendants to truck drivers to a professional manager (Getinet, 2007).

\subsection{Contribution of Chicken Rearing for Smallholder Farmers}

Smallholder-farming families, landless labourers, and people with incomes below the poverty line can raise chicken with low inputs and harvest the benefits of eggs and meat via scavenging feed with a small amount of supplementation. Family chicken meat and eggs contribute $20-30 \%$ to the total animal protein supply in lowincome and food-deficit countries (Sonaiya, 2004)

chicken provide major opportunities for increased protein production and incomes for smallholder farmers because of short generation interval, high rate of productivity, the ease with which its products can be supplied to different areas, the ease with which its products can be sold due to their relatively low economic values, its minimal association with religious taboos and its complementary role played with other crop-livestock activities (Makuza et al., 2000).

In most developing countries, for poor households, village chickens play a major role in the improvement of households' food security and poverty alleviation (Adongo, 2004, Moreki et al., 2010). Village poultry provides the owners of the chicken with nutritional and economic benefits with very minimal use of inputs or without any inputs. They provide their owners with economic and nutritional benefits with little or no inputs (Reta, 2009; Moreki et al., 2010).

As evidenced by studies in Southern parts of Ethiopia which showed that about $71.4 \%$ and $28.6 \%$ of chickens raised by the rural community were used for eggs and meat production purposes, respectively (Tadelle et al., 2003). Therefore, improved productivity of the chicken rearing would have a direct positive impact on farmers' income and nutrition.

The chicken provides readily harvestable animal protein to rural households (Kitalyi, 1998; Hailemichael et al., 2016), in their study on the characterization of the smallholder poultry production and marketing system, in some parts of Ethiopia indicated that there are fewer religious or social taboos associated with poultry keeping and consumption and has symbolic importance within the context of socio-cultural and religious functions.

Jacques (2012), in his study on the contribution of poultry farming in the socio-economic development of Rwandan rural areas, supported the literature that village poultry are significant for their nutritional and/or economic value, and also play a significant role in society through their contribution to the cultural and social life 
of rural people. The serving of a chicken dish is often in many parts of Africa a way of welcoming high-status visitors or honouring affinity and kinship (Jacques, 2012). Village poultry is also a useful tool to help poor rural households to recover from disasters, and it provides a practical and effective first step in alleviating abject rural poverty (Sodjinou, 2011).

A study in Ethiopia by Meseret et al. (2011), on marketing systems, socio-economic role, and intra-household dynamics of indigenous chicken reported that households spend the money obtained from chicken and egg sale for the purchase of items for home consumption and cover educational materials and other immediate cash needs from the school. Alders and Pym (2009) and Sodjinou (2011); supported that the different impact studies have demonstrated that income from the sale of poultry eggs in South Asia is used to send children to school and begin the process of asset accumulation. Muchadeyi et al. (2004), mentioned that in Zimbabwe chickens were also sold to cover school fees, medical costs, buy food items for household consumption, and paying village taxes.

\subsection{Factors Affecting Smallholder Farmers' Discussion to Participate in Improved Chicken Rearing 3.5.1 Agro-ecology}

Exotic chicken distributed to farmers in different agro-climatic zones is exposed to various risk factors that predispose for high chicken losses (Alemneh and Getachew, 2019). An agro-ecological pattern of Ethiopia is broadly divided into five zones (frost, highland, temperate, lowland and desert) based on altitude, temperature, rainfall pattern and distribution, and agricultural production systems (Birhanu and Poulton, 2012). Most of the sedentary agricultural practices are located in the highlands while the semi-arid and arid lowlands are dominated by agro-pastoral and pastoral production systems (Birhanu and Poulton, 2012). The degree to which village chicken production is integrated with the smallholder farming systems differs depending on the socio-economic, cultural, agro-ecological, and biological factors within each system (Muchadeyi et al., 2007).

In Ethiopia, Moges et al. (2010) reported that in the Northwest part of Ethiopia of the Amhara Region, the chicken flock size per household is 11.6, 13.9, and 13.4 in highland, mid-altitude, and lowland agro-ecological zones, respectively. Whereas, in Western Amhara Region, chicken flock sizes per household are 8.5, 7.4, and 8.4 in the highland, mid-altitude, and lowland areas, respectively, with high egg production per clutch, is found in highland agro-ecology than in lowlands (Worku et al., 2012). In-lined, in the lowland area of Oromiya region (Mid Rift Valley area), the mean chicken flock size per household is 13 chicken of the average flock size of exotic chicken breed per household was 0.76 (Leta and Endalew, 2010).

\subsubsection{Crop production}

In Ethiopia, poultry production is mostly concentrated in areas where crop production is concentrated (Gezahegn et al., 2009) because crop and livestock production in the highlands of Ethiopia are highly integrated and mixed. Availability of grain supplement for chicken varies with activities such as land preparation, sowing, harvesting, and grain availability in the household, a season of the year. Grain deficient countries like Ethiopia, adopting intensive poultry industry are discouraged by the severe shortage of grain unless the grain production in the country is improved considerably (Tadelle et al., 1999; Ermias et al. 2015). Such a system cannot be economically sustainable and socially acceptable. In Western Amhara Region of Ethiopia, the type of grains used as chicken feed supplementation varies among agro-ecologies, which is related to the type of crops grown. In the lowland areas, households used about $70 \%$ and $22 \%$ of maize and wheat, respectively, as essential grain supplements for their chicken. However, about $48 \%$ of the households in the highland mainly used wheat as a common feed supplement followed by maize (Worku et al., 2012).

\subsubsection{Family members}

In Ethiopia, the majority of village chicken production (92.4\%) is owned by females and children and most of the time the women and children are responsible for chicken rearing, while the men are responsible for other off-farm activities (Leta and Bekana, 2010; Moges et al., 2010). Chicken is sources of self-reliance for women (Aklilu et al., 2007). Mostly, men are responsible for a few activities like construction of shelter (Moges et al., 2010). Often children own one or two birds to meet the costs of school materials (Hailemariam et al., 2006). Regarding household heading and wealth status, in the Tigray Regional State of Ethiopia, male-headed households keep larger chicken flocks than female-headed households (Aklilu, 2007).

\subsection{Challenges and Opportunities for Improved Chicken Rearing in Ethiopia}

However, the Ethiopian poultry production and breeds supply are in advancing way, there are still challenges that constantly face poultry farms and farmers (Hinsemu, 2018). Like feed availability and quality, disease and predators, extension problems, exotic chicken adaptation challenges, genetic dilution of local breeds, and veterinary service shortages are the major today's poultry sector headaches (Dessie et al., 2013).

\subsubsection{Challenges}

\subsubsection{Adoption challenges}

According to the Ministry of Agriculture, in Ethiopia, like many African countries, attempts have been made at various times to improve local chicken production through the introduction of exotic chicken breeds. Despite this 
huge distribution of exotic chicken breeds, the contribution of improved chicken breeds in the current production system is very low. Some studies on the adoption of poultry technology in the highlands of Ethiopia indicated that adoption has been limited by a set of factors such as lack of knowledge on chicken husbandry (feeding, housing, health care.), lack of complementary inputs (feed, alternative breeds), environmental changes and high susceptibility of chicken, lack of strong extension follow up and high disease prevalence (Tamir et al., 2015).

\subsubsection{Disease and predators}

Smallholder farmers respond differently in times of disease occurrence; they do nothing, use ethno veterinary medicine, modern (conventional) medicine, or medicine originally intended for humans (Mapiye and Sibanda, 2005). High percentages of farmers do not offer health interventions to sick birds (Maphosa et al., 2004)

Many reports showed that Newcastle disease (ND), Infectious Bursal Disease (IBD) or Gumboro, Marek Disease (GMD), Fowl typhoid, Cholera, mycoplasmosis, and coccidiosis are widely distributed in most African countries, Ethiopia is not the exception to this situation (Alem, 2014). The Ethiopian indigenous flocks are said to be relatively disease resistant and adapted to their environment. However, the survival rates of chicks kept under natural brooding conditions are considered to be very low. Disease and predators are known to be the major causes of mortality in the country (Dana, 2011).

There are no practices (even means) of isolating sick birds from the household flocks and dead birds could sometimes be offered or left for either domestic or wild predators. The limitation of veterinary services such as drug, vaccine, and consultancy to the rural farmers are the gaps for the occurrence of the loss due to diseases and predators (Tadelle, 2015). The predation is strongly associated with the rainy season. The predators include primarily birds of prey such as vultures, which prey only on chicken, and wild mammals such as cats and foxes, which prey on mature birds as well as chicks (Alemneh and Getachew, 2019).

\subsubsection{Imbalance between demand and supply of improved chickens}

There is a chronic shortage supply of day-old chicks, pullets, and cockerels in Ethiopia. This leads to many smallholder farmers abandoning poultry keeping because their poultry houses will often be empty for months on end whilst they are waiting for new supplies from the hatcheries. Although the available hatching capacity is adequate; its performance is rather poor and needs improvement (Hailemariam, 2015).

\subsubsection{Feed availability and utilization}

Poultry feed and nutrition is one of the most critical constraints to poultry production under both the rural smallholder and large-scale systems in Ethiopia. The problem is mainly associated with a lack of processing facilities, inconsistent availability, and distribution, and sub-standard quality of processed feeds, when available (Tadelle, 2002). There is no purposeful feeding of chickens under the village conditions in Ethiopia and scavenging is almost the only source of diet. Scavenging the feed resource base for local birds is inadequate and variable depending on the season.

The amount of feed available for scavenging with the carrying capacity of the land areas and flock dynamics across the different seasons and agro-ecologies is still not adequately quantified. However, studies conducted in three villages of the central highlands with different altitudes and three different seasons revealed that the materials present in the crop, as visually observed are, seeds, plant materials, worms, insects, and unidentified materials. Regular availability of good quality ingredients and a fully balanced complete feed are essential for efficient poultry production. The most serious problems arise from the unavailability of suitable micro-nutrient sources, vitamins, and minerals (Dessie, et al., 2013).

\subsubsection{Market accessibility}

The marketing of poultry products offers an opportunity for smallholder producers to increase their small cash incomes (Tung. and Costales, 2007). However, market access is crucial for the realization of this opportunity. At a regional, provincial, and national level, market participation by smallholder farming entrepreneurs is critical for sustainable agriculture and economic growth (World Bank, 2013). Farming household members mentioned in interviews that proximity to a village or a regional town affects their involvement in poultry production. They said many farmers in remote areas are not involved in poultry keeping because local demand is low (Aklilu et al., 2007).

\subsubsection{Gender}

Women can work in small-scale broiler farms while maintaining religious and social norms (Kazimoto, 2013). Abadi et al. (2017) researched the analysis of factors affecting the adoption of exotic chicken breed production in the northwestern zone of Tigray, Ethiopia. He concluded in his result, male-headed households were better at adopting the exotic poultry breeds than female-headed households. This could be due to the reason that maleheaded households have a better financial capacity to buy exotic poultry breeds and have better information access about the technology than their counterpart. And the similar report was recorded by Ochieng et al. (2012), which justified that male-headed farmers were better at adopting chickens.

Gender analysis is a tool for understanding men and women's roles and the responsibilities in various activities, their use of resources, access and control to resources and benefits, participation in decision-making, and contribution to household income and food security (Kusina et al., 2001). The involvement in different types of agricultural work for men and women in most African communities depends mostly on social, cultural, local 
customs, and religious influence (Dassie and Ogle, 1996; Tadelle et al., 2001). The role of women in farming and village chicken practices was, until recently, largely unrecognized (Mapiye et al., 2008).

\subsubsection{Lack of extension education}

Farmers who have accessed training are more likely to adopt the breeds the reason is that training increases the knowledge of producers which in turn helps them to undertake informed decisions (Tamir et al., 2015). Lack of extension services is among the constraints that hinder the development of the poultry industry in developing countries (Hinsemu, 2018). Although extension and research are well-organized systems that design and disseminate technological innovations to farmers, little emphasis has been given to local chicken research and extension (Ali, 2012). Research conducted in Ethiopia by (Mekonnen, 2007) revealed that extension linkage between research output and the ministry of livestock and the farmers are found to be extremely weak.

\subsubsection{Lack of credit}

Improved management intervention is required to achieve increased productivity of improved chicken rearing for mitigating constraints such as diseases, poor feeds, and housing. The management intervention package designed to improve the productivity of improved chicken rearing includes housing, feed supplementation, vaccination, brooding, and chick-rearing (Olwande, et al., 2010). These management interventions require more labour and capital input than the extensive system and make greater demands on unpaid labour (Ngeno et al., 2010). Large amounts of input are required because many farmers shy away from adopting a management intervention package due to a lack of enough capital (Ochieng et al., 2011). Access to capital according to Olaniyi et al. (2008) has been a severe constraint to the utilization of improved chicken rearing technology. A study on the adoption of chicken breeds in the highlands of Ethiopia indicated that adoption has been limited by a set of factors including lack of credit (Tadelle, et $a l ., 2003$ ).

\subsubsection{Opportunities for improved chicken rearing in Ethiopia}

- Tool for Poverty alleviation and women's empowerment

Forty-four percent (44\%) of broiler beneficiaries were women. It provided employment opportunities and generated family income for them and thus, their status in family and society has been enhanced. Their relationship with the husband has also been improved after the adoption of broiler-packages (Rahman et al., 2006). A large number of women in the household often with the assistance of children actively engaged in the production of chicken, which helps them to generate revenue and/or complement the nutrition requirements of the family (Tesfahun et al., 2018).

African Chicken Genetic Gains Program (2017), prepared farmer training manuals for poultry management (including animal healthcare) have been published in Amharic and Oromo languages and made available to endusers. Formulations for chicks, growers, and layers were done using local ingredients targeting commercial, semiintensive, and scavenging systems (Dessie, 2018).

The ongoing national poultry extension package of the Ministry comprises of the distribution of 3-month-old exotic pullets and cockerels. The ministry promoted a scheme whereby cockerels and pullets of Rhode Island Red (RIR) were distributed from the breeding and multiplication centers to subsistence farmers (Demese et al., 2010)

- The government is investing in livestock sector development

According to Demese et al. (2010), MRDA drawn up a development strategy for poultry and poultry products indicates that there are plans to bring about improvements through five key measures. The measures are the following which is: Properly delineating potential production areas; organizing producers into different specialized tasks and linking them up through market chains (e.g. fertile egg producers, hatchery and chick growers, pullet growers, broiler growers, feed producers, health care takers); improving input services (increasing the production capacity of existing poultry-multiplication centers, establishing new parent stock farms and chick-rearing centers); Establishing a new distribution style of focusing on potential villages that could create easy access to such input services as improved feed and health, rather than scattering efforts thinly over long distances and motivating private-sector participation in poultry development by linking commercial farms with small-holders in a market chain.

\section{E The existence of poultry projects in developing countries}

Numbers of NGOs and FAO are also involved in the implementation of poultry development projects to support vulnerable households. Donors and NGOs involved in training on household poultry and hay-box chick brooding technology and distribution of chicks of exotic breeds. They also assisted the implementation of national/regional training courses accompanied by the distribution of chicks and pullets/cockerels and to raise awareness on avian and human Influenza Smallholder poultry production has been a frequent sub-component of several donor-funded projects, for example, the credit project of the International Fund for Agricultural Development (IFAD) targeting poorer rural women (Jobre, 2007).

\section{CONCLUSION AND RECOMMENDATION \\ 4.1 Conclusion}

* Based on the review, the following major conclusions were drawn. 
The ministry of agriculture and rural development of the country have been multiplied and disseminated several improved chicken breeds to increase the chicken contribution to income and dietary diversity of the household. Improved chicken has an important role in smallholder farmers' economic, social, and cultural benefit for the parts of Ethiopia. And also improved chicken rearing can play a key role in poverty alleviation, nutrition, and food security.

Even though improved chicken rearing has such key roles to smallholder farmers of the country, their rearing systems were affected by different constraints across the regions with negative impacts on the smallholder farmers' life. Such factors include adoption challenges or problems, the imbalance between demand and supply of improved chickens, lack of feed availability and utilization, agro-ecology problems, disease, market accessibility, less gender consideration, the inefficiency of extension education, and lack of credit are the factors that affect smallholder farmers' discussion to participate in improved chicken rearing in Ethiopia.

\subsection{Recommendations}

* Based on the above conclusion of the review, the following recommendations were forwarded.

$\checkmark$ The extension agencies and other concerned departments to manipulate these crucial factors to bring about desirable changes in the participation of smallholder farmers in improved chicken rearing in Ethiopia.

$\$$ The skills of smallholder farmers in all aspects of improved chicken management must be improved through training and education.

* Improved chicken should be supplied for all smallholder farmers in all regions year-round at a fair price.

* An adequate supply of high-quality feed at all times for smallholder farmers in all regions of Ethiopia at a reasonable price.

* Proper veterinary services such as timely vaccination should be ensured before the occurrence of the diseases.

* The marketing system must be improved, for the benefit of both chicken rearer and consumers in all regions of Ethiopia.

$\$$ More women should also be considered to increase complete understanding about the adoption of improved chickens in rural areas.

* Smallholder chicken producer or rearer farmers should also be provided with credits, taking into accounts the economic circumstances and socio-cultural context in which the beneficiaries live.

* Also, to increase the smallholder farmers' decision to participate in improved chicken rearing of poultry technology of the country, frequent extension services, teaching, training, and promotion should be given.

\section{REFERENCES}

Abadi, T., Gezahegn, M., and Teklehaimanot, A., 2017. Analysis of factors affecting the adoption of exotic chicken breed production in the northwestern zone of Tigray, Ethiopia. International Journal of Economics, Commerce and Management, 4(11), pp.127-137. Addis Ababa, Ethiopia.

Adongo, J., 2004. The comparative advantage of a thermotolerant I-2 vaccine in the control of Newcastle disease in village chickens in Ghana. Rural Poultry E-Newsletter, Third Edition GRM International PTY LTD. 2. http://www.iaea.org/nafa/d3/ mtc/ghana.pdf.

Afrimash Affiliates Program, 2020. An affiliate advertising program designed to provide a means for us to earn commissions by linking to Afrimash.com and affiliated sites.

Aklilu, H.A., Udo, H.M.J., Almekinders, C.J.M., and Van der Zijpp, A.J., 2008. How resource-poor households value and access poultry: Village poultry keeping in Tigray, Ethiopia. Agricultural Systems, 96(1-3), pp.175183.

Alders, R., and Pym, R., 2009. Village poultry: Still important to millions, eight thousand years after domestication. World's Poultry Science Journal 65:181-190.

Alem T., 2014. Production and reproduction performance of rural poultry in lowland and midland agro-ecological zones of central Tigray, Northern Ethiopia. African Journal of Agriculture 9(49): 3531-3539.

Alemneh, T., and Getabalew, M., 2019. Exotic chicken production performance, status, and challenges in Ethiopia. Int J Vet Sci Res, 5(2), pp.039-045.

Alemu, D., Degefe, T., Ferede, S., Nzietchueng, S., and Roy, D., 2008. Overview and background paper on Ethiopia's poultry sector: Relevance for HPAI research in Ethiopia.

Ali S., 2012. Family Poultry as a Tool in Alleviating Environmental Hazards in Settled Areas of Transhumant Families in Gezira Scheme Sudan. Asian Journal of Rural Development 2: 1-12.

Asgedom, A.H., 2007. Village poultry in Ethiopia: socio-technical analysis and learning with farmers.

Asresie, A., Eshetu, M., and Adigrat, E., 2015. Traditional chicken production system and marketing in Ethiopia: a review. J Mark Consum Res, 8, pp.27-34.

Becx, G.A., Slingerland, M.A., and Rabbinge, R., 2011. Pro-poor sourcing models that enable smallholder entrepreneurship: Working document presented 14 June 2011 at 2nd International Conference on 
Sustainability Transitions, in Lund, Sweden.

Berhanu, K., and Poulton, C., 2014. The political economy of agricultural extension policy in Ethiopia: economic growth and political control. Development policy review, 32(s2), pp.s197-s213.

Biratu, K., and Haile, S., 2016. Demonstration and Performance Evaluation of "Potchefstroom Koekoek" Chicken Package at Jimma Zone, South-Western Ethiopia.

Bogale, A. and Edae, C., 2020. Review on Productive and Reproductive Performance of Exotic Chicken Breed in Ethiopia.

Bush, J., 2006. The threat of avian flu predicted impacts on rural livelihoods in Southern Nation, Nationalities and Peoples Region (SNNPR), Ethiopia.

CSA, 2015. Agricultural sample survey Vol. II. Statistical Bulletin No. 578. CSA, Addis Ababa, Ethiopia.

CSA, 2017. Agricultural sample survey report on livestock and characteristics. Addis Abeba Ethiopia.

Chris Lesley, 2020. ISA Brown Chicken Care Guide: Temperament and Egg Laying Updated: August 5

Dana, N., 2011. Breeding programs for indigenous chicken in Ethiopia analysis of diversity in production systems and chicken populations (Doctoral dissertation, Wageningen University).

Dana, N., Van der Waaij, L.H., Dessie, T. and van Arendonk, J.A., 2010. Production objectives and trait preferences of village poultry producers of Ethiopia: implications for designing breeding schemes utilizing indigenous chicken genetic resources. Tropical animal health and production, 42(7), pp.1519-1529.

Demeke S., 2008. Poultry sector review: Analysis of the poultry sector in Ethiopia." Jimma, Ethiopia.

Demeke, S., 2007. Suitability of hay-box brooding technology to rural household poultry production system. Livestock Research for rural development, 19(1), pp.1-9.

Demese, C., Berhanu, A., and John, M., 2010. Ethiopia's agricultural sector policy and investment framework (PIF). MoARD (ed.). Addis Ababa, Ethiopia.

Dessie, T., 2018. Progress narrative: African Chicken Genetic Gains program.

Dessie, T., and Ogle, B., 1996. Studies on poultry production systems in the Central Highlands of Ethiopia. Swedish University of Agricultural Sciences (Doctoral dissertation, MSc thesis, Department of Animal Nutrition and management).

Dessie, T., Esatu, W., Waaij, L.V., Zegeye, F., Gizaw, S., Mwai, O. and Arendonk, J.V., 2013. Village chicken production in the central and western highlands of Ethiopia: Characteristics and strategies for improvement. ILRI (aka ILCA and ILRAD).

Dixon, J., Taniguchi, K., and Wattenbach, H., 2003. Approaches to assessing the impact of globalization on African smallholders: Household and village economy modelling. Proceedings of a working session on Globalization and the African Smallholder Study. FAO (Agricultural Support Systems Division [AGS] and the Agricultural and Development Economics Division [ESA]) and the World Bank.

Ermias T., Berhan T., and Zemelak, S., 2015. Characterization of husbandry practices, adoption, and impact of village poultry technology packages in the Central Oromia Region, Ethiopia. Unpublished dissertation in partial fulfilment of the requirements for the degree of Doctor of Philosophy, Addis Ababa University, Debre Zeit, Ethiopia.

Fessiha, M., Aberra, M., and Tadelle, D., 2010. Assessment of village chicken production system and evaluation of the productive and reproductive performance of local chicken ecotype in Bure district, North West Ethiopia. African Journal of Agricultural Research, 5(13), pp.1739-1748.

Getinet H., 2007. Marketing and sales strategies of elfora agro-industries plc, Addis Ababa Ethiopia. Link: https://bit.ly/2G9Z2gB.

Getiso, A., Bekele, B., Zeleke, B., Gabriel, D., Tadesse, A., Abraham, E., and Jemal, H., 2017. Production performance of Sasso (distributed by the-chicken private poultry farms) and Bovans brown chickens breed under village production system in three agro-ecologies of Southern Nations, Nationalities, and Peoples Regional State (SNNPR), Ethiopia. International Journal of Livestock Production, 8(9), pp.145-157.

Getu, A., 2014. Review on Ethiopian poultry origin, domestication, classification, and characterization of its production systems. Middle-east journal of scientific research, 22(7), pp.1025-1032.

Gezahegn A., Dorene, A.M., Ekin B. and Devesh, R. (2009): Investigating the role of poultry in

Habte, T., Amare, A., Bettridge, J., Collins, M., Christley, R., and Wigley, P., 2017. Guide to chicken health and management in Ethiopia. ILRI Manual, 25, pp.1-25.

Haftu K., 2016. A Review Exotic Chicken Status, Production Performance, and Constraints in Ethiopia. Asian Journal of Poultry Science, 10: 30-39.

Hailemariam, A., and Zemedu, L.,2015. The implication for Information Generation and Exchange: A Review.

Hailemichael, A., Gebremedhin, B., Gizaw, S., and Tegegne, A., 2016. Analysis of village poultry value chain in Ethiopia: Implications for action research and development.

Hinsemu, F., 2018. Review on Challenges and Opportunities of Poultry Breeds. J. Dairy Vet. Sci, 7, pp.1

Jacques B.S.J., 2012. Contribution of poultry farming in the socio-economic development of Rwandan rural areas. Kigali, Rwanda: National University of Rwanda. 
Jobre Y (2007) Urgent intervention for the early detection, prevention, and control of Avian Influenza in Ethiopia.

Kazimoto, R., 2013. The Contribution of the Poultry Farming Project to the Improvement of Food Security and Income Generating in Kunduchi Mtongani Community-Kinondoni Municipal (Doctoral dissertation, The Open University of Tanzania).

Kejela, Y., Banerjee, S., Taye, M., and Beyan, M., 2019. Urban poultry production systems and constraints of local and exotic chickens reared in Yirgalem and Hawassa Towns, Ethiopia. International Journal of Livestock Production, 10(2), pp.62-69.

Kelemework, F., Kassa, H., and Ababa, A., 2006. Ethiopian Economic Association/Ethiopian Economic Policy Research Institute (EEA/EEPRI).

Kibreab, Y., Zelalem, A., Kassa, T., Dakamo, F., Dessiye, T., Hilemariyam, G., Fisseha, M., Dawit, H., Tegbaru, G. and Cherinet, R., 2016. Poultry Production, Management, and Marketing System at Selected Districts of Kafa and Benchmaji Zone, South West Ethiopia. Journal of Biology, Agriculture and Healthcare, 6(11), pp.83-96.

Kitalyi, A.J., 1998. Village chicken production systems in rural Africa: Household food security and gender issues (No. 142). Food \& Agriculture Org.

Leta, S. and Endalew, B., 2010. Survey on village based chicken production and utilization system in mid Rift Valley of Oromia, Ethiopia. Global Veterinaria, 5(4), pp.198-203.

Leta, S., and Endalew, B., 2010. Survey on village-based chicken production and utilization system in mid-Rift Valley of Oromia, Ethiopia. Global Veterinaria, 5(4), pp.198-203.

livelihoods and the potential impact of HPAI on livelihoods in Ethiopia. Research Report.

Makuza, S.M., Muchenje, V., and Chiyanike, S., 2000. Genetic evaluation of grade, appendix, and pedigree cow classes in Holstein, Jersey, and crossbred dairy breeds in Zimbabwe. In Proceedings of the Regional Conference.

Maphosa, T., J. F. Kusina, N. T. Kusina, S. Makuza, and S. Sibanda. 2004. A monitoring study comparing the production of village chickens between communal (Nharira) and small-scale commercial (Lancashire) farming areas in Zimbabwe. Livestock Res. Rural Dev. 16 (7). http://www.cipav.org.co/ 1rrd//rrd16/7/maph16048.htm. Accessed: 28/10/2005.

Mapiye, C., and S. Sibanda. 2005. Constraints and opportunities of village chicken production systems in the smallholder sector of Rushinga District of Zimbabwe. Livestock Res. Rural Dev. 17 (10). http://www.cipav.org.co//rrd//rrd17/10/mapi17115.htm. Accessed: 04/11/2005

Mapiye, C., Mwale, M., Mupangwa, J.F., Chimonyo, M., Foti, R. and Mutenje, M.J., 2008. A research review of village chicken production constraints and opportunities in Zimbabwe. Asian-Australasian Journal of Animal Sciences, 21(11), pp.1680-1688.

Mekonnen, G., 2007. Characterization of smallholder poultry production and marketing system of Dale, Wonsho, and Loka Abaya Weredas of Southern Ethiopia. Awassa College of Agriculture, Hawassa University (MSc thesis)

Meseret, M., Solomon, D., and Tadelle, D., 2011. Marketing system, socio-economic role, and intrahousehold dynamics of indigenous chicken in Gomma Wereda, Jimma Zone, Ethiopia. Livestock Research for rural development, 23(6).

Milkias, M., 2016. Review of exotic chicken status, production performance, and constraints in Ethiopia. institutions, 6(15).

Moges F., Mellesse A., and Dessie T., 2010. Assessment of village chicken production system and evaluation of the productive and reproductive performance of local chicken ecotype in Bure district, North West Ethiopia. Afri. J. Agri. Resea. 5:1739-1748.

Molla, M., 2010. Characterization of village chicken production and marketing system in Gomma Wereda, Jimma Zone, Ethiopia (Doctoral dissertation, Jimma University). Meseret, M., Solomon, D., and Tadelle, D., 2011. Marketing system, socio-economic role, and intrahousehold dynamics of indigenous chicken in Gomma Woreda, Jimma Zone, Ethiopia. Livestock Research for rural development, 23(6).

Moreki, J., Dikeme, R., and Poroga, B., 2010. The role of village poultry in food security and HIV/AIDS mitigation in Chobe District of Botswana. Livestock Research for Rural Development 22:1-7.

Muchadeyi F., Sibanda S., Kusina N., Kusina J., and Makuza, S., 2004. The village chicken production system in Rushinga District of Zimbabwe. Livestock Research for Rural Development 16:2004.

Muchadeyi, F.C., Editing, H., Wollny, C.B.A., Groeneveld, E., Makuza, S.M., Shamseldin, R., Simianer, H., and Weigend, S., 2007. Absence of population substructuring in Zimbabwe chicken ecotypes inferred using microsatellite analysis. Animal Genetics, 38(4), pp.332-339.

Nasser M, Lohr GY, Mebratu KH, Zessin MPO, Baumann Z, et al., 2000. Oral Newcastle disease vaccination trials in Ethiopia. Avian Pathology: 2734. Link: https://bit.ly/2XUJck7.

Ngeno V., Langat B., Sulo T., Wendy R., and Kipsat M. J., 2010. Adoption of commercial poultry production among periurban farmers in Kericho, Kunicipality, Kenya. 
[http://www.Kari.org/biennia/conference12/clocs/ADOPTION OF COMMERCIAL POULTRY PRODUCTION] site visited on 24/04/2011.growth and political control. May 2012, Working Paper 042. www.future-agricultures.org.

Nigussie, D., 2011. Breeding programs for indigenous chicken in Ethiopia: analysis of diversity in production systems and chicken populations. Department of Animal Science, School of Graduate Studies, Haramaya University, Dire Dawa, Ethiopia. (MSc thesis submitted).

Ochieng J., Owuor G., Bebe B. O. and Ochieng, D. O., 2011. Effect of management interventions on the productive performance of indigenous chicken in Western Kenya. Livestock Research for Rural Development 23 (5): 2011.

Ochieng, J., Owuor, G., and Bebe, B.O., 2012. Determinants of adoption of management interventions in indigenous chicken production in Kenya. African Journal of Agricultural and Resource Economics, 7(3112016-5598), pp.39-50

Olaniyi, O.A., Adesiyan, I.O., and Ayoade, R.A., 2008. Constraints to the utilization of poultry production technology among farmers in Oyo State, Nigeria. Journal of Human Ecology, 24(4), pp.305-309.

Olwande P. O., Ogara, W. O., Okuth, S. O., Muchemi, G., Okoth, E., Odindo, M. O. and Adhiambo, R. F., 2010. Assessing the productivity of indigenous chickens in an extensive management system in southern Nyanza, Kenya. Tropical Animal Health Production 42(2): 283-288.

Rahman, S.M.A., Sayeed, M.A., Sarker, N.R., and Alam, J., 2006. Impact of improved poultry management technique on the socio-economic condition of broiler beneficiaries. Journal of the Bangladesh Agricultural University, 4(452-2018-3928), pp.401-411.

Reta D., 2009. Understanding the role of indigenous chickens during the long walk to food security in Ethiopia. Livestock Research for Rural Development 21:8. Retrieved December 14, 2014.

Sisay, T., Alemayehu, K., And Wuletaw, Z., 2017. Population dynamics and performance of exotic versus indigenous chicken population in the selected districts of North Western Amhara, Ethiopia. Tropical Drylands, 1(2), pp.90-99.

Sodjinou, E., 2011. Poultry-based intervention as a tool for poverty reduction and gender empowerment: empirical evidence from Benin (Doctoral dissertation, University of Copenhagen, Faculty of Life Sciences, Department of Food and Resource Economics).

Sonaiya E., 2004. Direct assessment of nutrient resources in free-range and scavenging sys-terms. World's Poult Sci J 60: 523-535. Link: https://bit.ly/2Jx9ReI.

Tadelle D. and B. Ogle, 2001. Village poultry production systems in the central highlands of Ethiopia. Trop. Anim. Health and Prod. 33(6):521-537.

Tadelle D., 2015. Participatory evaluation of chicken health and production constraints in Ethiopia. Preventive Veterinary Medicine 118 (11): 117-127.

Tadelle, D., Alemu, Y., and Peters, K., 2003. Village chicken production systems in Ethiopia: Use patterns and performance valuation and chicken products and socio-economic functions of chicken.

Tadelle, D., Nigusie, D., Alemu, Y., and Peters, K.J., 2002. The feed resource base and its potentials for increased poultry production in Ethiopia. World's Poultry Science Journal, 58(1), pp.77-87.

Tamir, Simegnew, Fessiha Moges, Yeshiwas Tilahun, and Molla Hile. "Determinants of adoption of exotic poultry breeds among smallholder poultry producers in North-Western Amhara Region, Ethiopia." Global Journal of Agricultural Economics \& Econometrics 3, no. 6 (2015): 162-168.

Tegegne, A., Gebremedhin, B., and Hoekstra, D., 2010. The livestock input supply and service provision in Ethiopia: Challenges and opportunities for market-oriented development.

Teklewold, H., Dadi, L., Yami, A., and Dana, N., 2006. Determinants of adoption of poultry technology: a doublehurdle approach. Livestock Research for rural development, 18(3), pp.1-14.

Temi Cole, 2020. What's The Best Pen For 1000 Birds Poultry Farm? (Pictures needed) Posted on March 2, 2019 (October 15, 2020)

Tesfahun, A., Bruno, J., Fasil, G., and Tadelle, D., 2018. Socio-economic, marketing, and gender aspects of village chicken production in the tropics: a review of the literature. Socio-economic, marketing, and gender aspects of village chicken production in the tropics: a review of the literature.

Tung, D.X., and Costales, A., 2007. Market participation of smallholder Poultry producers in northern Viet Nam. Rome: Food and agriculture organization of the United Nations.

Van Eekeren N., Maas A., Saatkamp Hand Verschuur M., 2006. Agrodok Hand book of Small-scale chicken production. (4th edn). 9. Link: https://bit.ly/32phTOj.

Wilson, R.T., 2010. Poultry production and performance in the Federal Democratic Republic of Ethiopia. World's Poultry Science Journal, 66(3), pp.441-454.

Wondmeneh, E., van Der Waaij, E.H., Tadelle, D., Udo, H.M.J. and Van Arendonk, J.A.M., 2014. Adoption of exotic chicken breeds by rural poultry keepers in Ethiopia. Acta Agriculturae Scandinavica, Section AAnimal Science, 64(4), pp.210-216. 
Worku Z., Melesse A., and T/Giorgis Y., 2012. Assessment of village chicken production system and the performance of local chicken populations in West Amhara Region of Ethiopia. J. Anim. Prod. Adv. 2: 199207.

World Bank Report, 2013. Growing Africa: Unlocking the Potential of Agribusiness. Accessed on 21 December 2013. URL: http://siteresources.worldbank.org.

Yenesew, A., Agraw, A., Yihenew, G., and Dessalegn, M., 2015. Poultry Production Manual. Bahir Dar University Capacity Building for Scaling up of Evidence Best Practices in Agricultural Production in Ethiopia (BDUCASCAPE) Working Paper, 14.

Zewdu, S., Kassa, B., Agza, B., and Alemu, F., 2013. Village chicken production systems in Metekel zone, Northwest Ethiopia. Wudpecker Journal of Agricultural Research, 2(9), pp.256-262. 